UDC 378.147.811

DOI: $10.31470 / 2415-3729-2019-10-9-24$

\title{
The Research of the Motivation Sphere of Future Electric Power Engineers to Study Foreign Language
}

\section{Nataliia Bilan}

Senior Lecturer of the Humanitarian Disciplines Department, Separated Subdivision of National University of Live and Environmental Sciences of Ukraine «Berezhany Agrotechnical Institute»

$\triangle 20$, Academichna Str., Berezhany, Ternopil Region, Ukraine, 47501 E-mail: natalja_bilan@ukr.net

ORCID: 0000-0002-9996-8593

Date of receipt of the article: September 28, 2019 Article accepted for publication: December 02, 2019

\section{Дослідження мотиваційної сфери майбутніх інженерів- енергетиків до вивчення іноземної мови}

\section{Наталія Миколаївна Білан}

старший викладач кафедри гуманітарних дисциплін, Відокремлений підрозділ Національного університету біоресурсів і природокористування України «Бережанський агротехнічний інститут»

$\triangle$ вул. Академічна, 20, м. Бережани, Тернопільська обл., Україна, 47501

Дата надходження статті: 28 вересня 2019 p. Стаття прийнята до друку: 02 грудня 2019 p.

\section{Abstract}

The article deals with the research of the structural components of students' motivational sphere towards learning a foreign language 
of professional orientation. It has been considered that the result of foreign language training of future electric power engineers and the desire to learn the professional language style depend on the level of motivation. There are five types of motives that encourage students to acquire a foreign language competence. The research reveals the essence of the concept of «motive of future electric power engineers to study foreign language», under which it is understood the structural element of motivation, being formed under the influence of external factors (strategy of development and implementation of international activities by technical Universities, the authority of teachers providing foreign-language training, the challenges of the information society, the innovations in the energy power sector, modern requirements to electric power specialties graduates) and internal needs of the individual (the desire to acquire up-to-date knowledge in the specialty, the will to succeed in the learning process and in the future professional activity). The holistic formation of educational, professional, communicative, personal, socio-cultural motives forms a complex of stimulating means aiming positive attitude of the students of electric power energy specialty to study a foreign language, which is carried out under the influence of external and internal motivation. Moreover the rate of studying the disciplines of the general training cycle by future electric power energy engineers on the bases of personal motives has been formed. It has been defined the priority of «Foreign language for professional orientation» among other nonlinguistic subjects, the study of which is envisaged by the educational and professional program of training the applicants for the specialty 141 «Electricity, electrical engineering and electromechanics». However the external factors that can increase students' internal motivation for foreign language training have been highlighted. They are an educational work practice at the foreign electric power plants; studying of selective professional disciplines in a foreign language; reading contemporary technical literature of a foreign publishing house; using of innovative technologies, modern teaching methods in practical courses in the disciplines «Foreign language for 
professional orientation», «Business foreign language»; organization and implementation of extracurricular work for students in a foreign language. It has been defined the results of the experimental work had been carried out by the method of empirical research, such as surveys, observations and comparisons. On the basis of the data obtained, the author of the article states that the motivational sphere of the future electric power engineers and encouraging them to study a foreign language is at a sufficient level, and considers that the formation process of motives and positive motivation of students for foreign language training requires further development and comprehensive expansion.

Key words: motivation sphere, motive, motivation, foreign language, future electric power engineers, student.

\section{References}

1. Aristova, N.O. (2008). Formuvannia motyvatsii vyvchennia inozemnoi movy u studentiv vyshchykh nelinhvistychnykh zakladiv [Formation of a foreign language learning motivation among the students of higher non-linguistic education establishments]. Extended abstract of candidate's thesis. Kyiv [in Ukrainian].

2. Honcharenko, S. (1997). Ukrainskyi pedahohichnyi slovnyk [Ukrainian Pedagogical Dictionary]. Kyiv : «Lybid» [in Ukrainian].

3. Entsyklopediia osvity (2008). [Encyclopaedia of Education]. Kyiv : «Yurinkom Inter» [in Ukrainian].

4. Klymenko, N.O. (2005). Formuvannia motyviv navchalnopiznavalnoi diialnosti studentiv vyshchykh navchalnykh zakladiv humanitarnoho profiliu [The formation of motives of educational and cognitive activity of students in higher educational establishments pertaining to the humanities]. Extended abstract of candidate's thesis. Luhansk [in Ukrainian].

5. Klochko, V.I. \& Kolomiiets, A.A. (2012). Formuvannia motyvatsii navchalno-piznavalnoi diialnosti studentiv tekhnichnykh spetsialnostei [The formation of motives of educational and cognitive activity of students in higher educational establishments]. Vinnytsia : VNTU [in Ukrainian]. 
6. Kolomiiets, A.A. (2011). Formuvannia motyvatsii navchalnopiznavalnoi diialnosti studentiv tekhnichnykh spetsialnostei zasobamy istoriohrafii [Formation of motivation of training and cognitive activity of students of technical specialties by means of historiography]. Candidate's thesis. Vinnytsia [in Ukrainian].

7. Podshyvailov, F.M. (2015). Psykholohichni chynnyky rozvytku motyvatsiinoi sfery osobystosti maibutnoho psykholoha [Psychological premises of the development of future psychologist's personality motivational sphere]. Candidate's thesis. Kyiv [in Ukrainian].

\section{Вступ}

Мотиваційна сфера - це дефінітивний чинник, який суттєво впливає на організацію та здійснення навчально-пізнавальної діяльності здобувачів вищої освіти. Мотиви визначають особистісне ставлення студентів до навчання, розвивають інтерес до змісту дисциплін циклу загальної і професійної підготовки, формують мотивацію до їх пріоритетного вивчення. Засвоєння фахових знань, оволодіння іноземною мовою професійного спрямування, набуття практичних навичок та умінь ними комплексно оперувати під час вирішення завдань репродуктивного, конструктивного, творчого характеру тощо - усі ці процеси відбуваються під дією мотивів, якими студенти-енергетики керуються в освітньому процесі. Від рівня сформованості мотиваційної сфери залежить поточний перебіг і кінцевий результат професійної підготовки майбутніх інженерів-енергетиків у закладах вищої освіти, а в майбутньому - реалізація себе як фахівця, самоосвіта, підвищення кваліфікації.

Ставлення здобувачів спеціальності 141 «Електроенергетика, електротехніка та електромеханіка» до навчання, вивчення іноземної мови, зокрема, можна розглядати з позицій, яким характерні протиріччя:

1) студент, який зосереджений на здобутті лише фахових знань і майбутній інженер-енергетик мотивований до 
всебічного розвитку, оволодіння професійною та іншомовною компетентностями на високому рівні;

2) випускник закладу вищої освіти як знавець лише здобутої спеціальності за фахом та особистість, обізнана у суміжних сферах, здатна навіть здійснювати усі види інженерної діяльності в умовах іншомовного середовища.

Фундаментальним для перелічених розбіжностей $\epsilon$ мотиваційна сфера, яка відображає відношення майбутніх інженерів-енергетиків до професійної підготовки, визначає їх активність в освітнього процесі, наполегливість у здобутті фахових та іншомовних знань. Відповідно виникає необхідність у формуванні мотивів та позитивної мотивації студентів до вивчення іноземної мови професійного спрямування, що й зумовлює актуальність проблеми нашого дослідження.

Проаналізувавши літературні джерела виявлено, що вченими зроблено вагомі напрацювання у вирішенні проблеми формування мотиваційної сфери здобувачів вищої освіти до різних видів навчальної діяльності. Зокрема, іiі розв'язання знайшло висвітлення у наукових публікаціях Н. Батрин, М. Вієвської, О. Гулай, С. Занюк, І. Зайцевої, Ю. Зіньковського, Н. Клименко, Н. Клочко, А. Коломієць, Т. Левченко, Г. Нітченко, Н. Мамаєвої, Ф. Подшивайлова. Загальні аспекти розвитку мотивів та мотивації студентів нелінгвістичних спеціальностей до вивчення іноземних мов у процесі професійної підготовки обгрунтовані Н. Арістовою, С. Король, О. Малінкою, О. Мацюк, О. Можаровською, О. Тинкалюк, І. Цар та іншими.

Формування у студентів мотивів до активної та ініціативної навчально-пізнавальної, науково-дослідної, культурно-виховної діяльності є однією з умов забезпечення якісної професійної підготовки майбутніх фахівців, оскільки особистісні мотиви націлюють їх на засвоєння певної сфери знань та викликають інтерес до самоосвіти (Клименко, 2005:3). Підтримуючи зазначену вище позицію науковця, а також беручи до уваги той факт, що іншомовні знання є невід'ємною складовою 
професійної компетентності сучасних фахівців, у тому числі й енергетичної галузі, вважаємо за доцільне визначити мотиви та види мотивації, які б спонукали студентів-енергетиків вивчати іноземну мову професійного спрямування.

Мета статті полягає у дослідженні структурних компонентів мотиваційної сфери майбутніх інженерів-енергетиків, їх впливу на іншомовну підготовку та рівень засвоєння метамови спеціальності 141 «Електроенергетика, електротехніка, електромеханіка».

\section{Матеріал і методи дослідження}

Для досягнення поставленої мети у ході дослідження було використано низку теоретичних та емпіричних методів наукового пошуку, зокрема - аналіз, синтез, узагальнення та систематизація наукової літератури, спостереження, опитування, порівняння.

\section{Результати та їх обговорення}

Перш ніж обгрунтувати означену нами проблему та запропонувати шляхи iii вирішення, 3'ясуємо сутність основних понять нашого дослідження «мотив», «мотивація», а також чинники, які зумовлюють їх виникнення.

У психолого-педагогічній літературі подаються різні наукові підходи щодо трактування поняття «мотив». Розглянемо деякі 3 них:

- інтегральний спосіб організації активності людини, будьяка іiі спонука, детермінантами якої є як внутрішні, так і зовнішні причини (Клименко, 2005:8);

- комплекс стимуляторів, інтегрованих 3 потребами особистості, який спонукає особистість до діяльності (Клочко \& Коломієць, 2012:16);

- усвідомлена потреба, яка супроводжується бажанням їі задовольнити (Подшивайлов, 2015:30).

Беручи до уваги позиції науковців, під мотивом майбутніх інженерів-енергетиків до вивчення іноземної мови розуміємо структурний елемент мотивації, який формується під дією 
зовнішніх чинників і внутрішніх потреб особистості. До зовнішніх чинників відносимо: стратегію розвитку та здійснення міжнародної діяльності технічними закладами вищої освіти; авторитет викладачів, які забезпечують іншомовну підготовку; виклики інформаційного суспільства; інновації в енергетичній галузі, сучасні вимоги до випускників енергетичних спеціальностей. Прагнення здобути актуальні знання зі спеціальності, бажання досягнути успіху в процесі навчання $\mathrm{i}$ в майбутній професійній діяльності викликані внутрішніми потребами студентів.

Система мотивів, яка спонукає особистість до конкретних форм діяльності або поведінки формує мотивацію (Гончаренко, 1997:217). В освітній сфері такою формою діяльності студентів є навчальна робота, яка визначається мотивацією учіння - складною системою спонукань, що зумовлюють спрямування активності індивіда на отримання, перетворення і збереження нового досвіду: знань, умінь, способів дій, вражень, уподобань. В енциклопедії освіти обгрунтовано три групи мотивуючих факторів, які утворюють структуру мотивації учіння. Перша група є джерелом активності, поштовхом формування якої є потреби та інстинкти. Складовими другої групи $є$ навчальні мотиви, мотивація учіння, від яких залежить спрямованість активності. До мотивуючих факторів третьої групи належать емоції, почуття, прагнення, бажання та установки, які зумовлюють і визначають спосіб регуляції і динаміки поведінки особистості в освітньому процесі (Енциклопедія освіти, 2008:528).

Беручи до уваги зазначене вище, вважаємо, що мотиваційну сферу майбутніх інженерів-енергетиків до вивчення іноземної мови професійного спрямування формують наступні компоненти: внутрішня потреба у вивченні дисципліни, інтерес до іншомовної підготовки, професійний мотив, бажання засвоїти метамову спеціальності, прагнення до самовдосконалення іншомовними засобами. 
3 метою дослідження мотиваційної сфери майбутніх інженерів-енергетиків, впливу іiі структурних компонентів на професійну та іншомовну підготовку, проведено вибіркове опитування серед здобувачів спеціальності 141 «Електроенергетика, електротехніка та електромеханіка» у ВП НУБіП України «Бережанський агротехнічний інститут».

За результатами емпіричного дослідження встановлено, що студенти свідомо надають пріоритетність предметам, обгрунтовують доцільність засвоєння тієї чи іншої дисципліни, враховуючи професійну сферу майбутньої діяльності. Основна увага 79 \% респондентів зосереджена на вивченні професійноорієнтованих дисциплін, а саме: електротехнічні матеріали, основи електропостачання, електричні апарати, електричні машини, електричні мережі, мікропроцесорна техніка, метрологія і електричні вимірювання, діагностування електрообладнання, технічний сервіс енергообладнання, теплоенергетичні установки і системи, енергоощадність та альтернативні джерела енергії тощо. Лише $21 \%$ майбутніх інженерів-енергетиків розглядають засвоєння предметів циклу загальної і професійної підготовки як єдине ціле, взаємодоповнюючі компоненти освітнього процесу, без оволодіння одного з яких здобуття фаху та навчання в цілому $є$ недостатньо якісним.

Задля виявлення ступеня зацікавленості студентів факультету «Енергетики та електротехніки» в іншомовній підготовці та доцільності вивчення «Іноземної мови за професійним спрямуванням» серед гуманітарних дисциплін, знаннями яких також повинна володіти кожна освічена людина, учасникам анкетування було запропоновано сформувати рейтинг предметів, керуючись особистими мотивами (Таблиця 1).

На основі рейтингового оцінювання, встановлено, що «Іноземна мова за професійним спрямуванням» займає першу позицію серед гуманітарних дисциплін, які входять до переліку предметів циклу загальної підготовки студентів у технічних закладах вищої освіти. Надання першочерговості навчальній 
дисципліні майбутні інженери-енергетики пояснюють тим, що розглядають іноземну мову як метамову спеціальності, знання якої є запорукою успішного працевлаштування на сучасному ринку праці, засобом вирішення особистісних і професійних завдань в іншомовному середовищі, способом самореалізації та вдосконалення фахової майстерності. Вважаємо, що зазначене обгрунтування можна розглядати як професійний мотив студентів-енергетиків до вивчення іноземної мови.

Таблиия 1

Рейтинг мотивованого вивчення гуманітарних дисциплін студентами-енергетиками

\begin{tabular}{|c|l|c|c|}
\hline $\begin{array}{c}\text { № } \\
\text { п/п }\end{array}$ & \multicolumn{1}{|c|}{ Навчальна дисципліна } & $\begin{array}{c}\text { Пріоритет } \\
\mathbf{y} \\
\text { вивченні }\end{array}$ & $\begin{array}{c}\text { Відсоток } \\
\text { студентів }\end{array}$ \\
\hline 1. & $\begin{array}{l}\text { Іноземна мова за професійним } \\
\text { спрямуванням }\end{array}$ & 1 & $64 \%$ \\
\hline 2. & $\begin{array}{l}\text { Українська мова за професійним } \\
\text { спрямуванням }\end{array}$ & 1 & $22 \%$ \\
\hline 3. & Історія української державності & 1 & $7 \%$ \\
\hline 4. & Філософія & 1 & $5 \%$ \\
\hline 5. & Етнокультурологія & 1 & $2 \%$ \\
\hline
\end{tabular}

На основі рейтингового оцінювання, встановлено, що «Іноземна мова за професійним спрямуванням» займає першу позицію серед гуманітарних дисциплін, які входять до переліку предметів циклу загальної підготовки студентів у технічних закладах вищої освіти. Надання першочерговості навчальній дисципліні майбутні інженери-енергетики пояснюють тим, що розглядають іноземну мову як метамову спеціальності, знання якої $є$ запорукою успішного працевлаштування на сучасному ринку праці, засобом вирішення особистісних і професійних 
завдань в іншомовному середовищі, способом самореалізації та вдосконалення фахової майстерності. Вважаємо, що зазначене обгрунтування можна розглядати як професійний мотив студентів-енергетиків до вивчення іноземної мови.

Слід також зазначити, що при об'єктивному аналізі даних, представлених у таблиці 1, необхідно враховувати наступний фактор - для студентів технічних спеціальностей притаманне переважно логічне мислення, тому формування позитивних мотивів до вивчення предметів і навчання в цілому обумовлене розумінням важливості матеріалу, усвідомленням його розгорнутості в часі (Коломієць, 2011:15). Крім цього, розвиток мотиваційної сфери здобувачів вищої освіти залежить від низки психолого-педагогічних чинників, а саме: організації освітнього процесу; змісту навчального матеріалу; міжособистісних відносин між викладачами i студентами; гнучкої системи оцінювання навчально-пізнавальної діяльності студентів; створення ситуації успіху на заняттях; високого рівня професійної компетентності викладача (Арістова, 2008:10).

На основі проведеного опитування визначено наступні види мотивів, якими керуються студенти-енергетики у процесі іншомовної підготовки:

1) навчальні (виконання програмних вимог, оволодіння метамовою енергетичної спеціальності);

2) професійні (розширення фахових знань іншомовними засобами, майбутне працевлаштування за кордоном);

3) особистісні (усвідомлення необхідності володіння іноземними мовами у сучасному світі);

4) комунікативні (прагнення спонтанно спілкуватися іноземною мовою у монологічній та діалогічній формах на довільну тематику, незалежно від ситуацій);

5) соціокультурні (інтерес до іншомовних країн, їх історії, культури, звичаїв, традицій тощо).

На рис. 1 представлено перелічені мотиви за ступенем володіння студентами. 


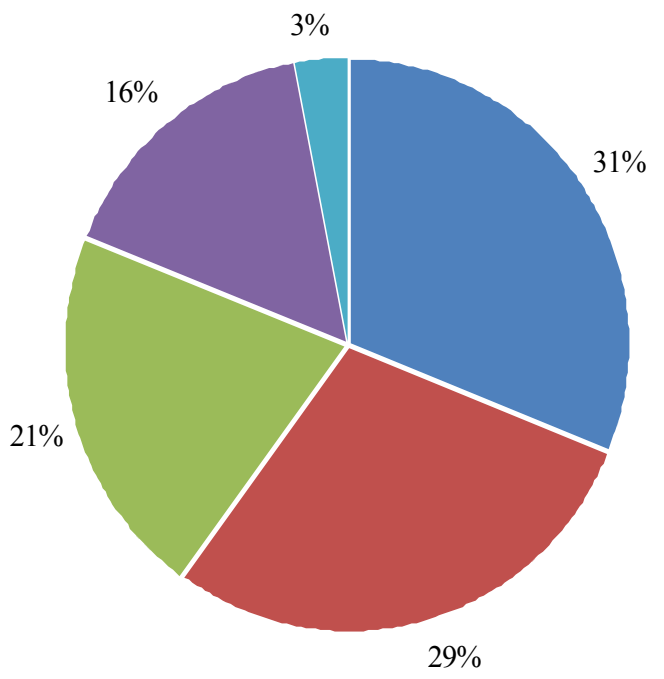

\section{Мотиви:}

навчальні

професійні

комунікативні

особистісні

соціокультурні

Рис. 1. Класифікація мотивів студентів-енергетиків до вивчення метамови спеціальності

На основі рейтингового оцінювання, встановлено, що «Іноземна мова за професійним спрямуванням» займає першу позицію серед гуманітарних дисциплін, які входять до переліку предметів циклу загальної підготовки студентів у технічних закладах вищої освіти. Надання першочерговості навчальній дисципліні майбутні інженери-енергетики пояснюють тим, що розглядають іноземну мову як метамову спеціальності, знання якої $є$ запорукою успішного працевлаштування на сучасному ринку праці, засобом вирішення особистісних і професійних завдань в іншомовному середовищі, способом самореалізації та вдосконалення фахової майстерності. Вважаємо, що зазначене обгрунтування можна розглядати як професійний мотив студентів-енергетиків до вивчення іноземної мови.

Рівень сформованості мотивів зумовлює розвиток мотивації. Вплив викладачів іноземних мов, міжнародна діяльність закладу 
вищої освіти, інтеграційні процеси в енергетичній галузі - під впливом цих факторів формується зовнішня мотивація студентів. Особистісні інтереси, самоусвідомлення значущості дисциплін «Іноземна мова за професійним спрямуванням», «Ділова іноземна мова» $є$ першоосновою для виникнення внутрішньої мотивації. Види мотивації, які переважають у майбутніх інженерів-енергетиків щодо успішного оволодіння метамовою майбутньої спеціальності, зображено на рис. 2.

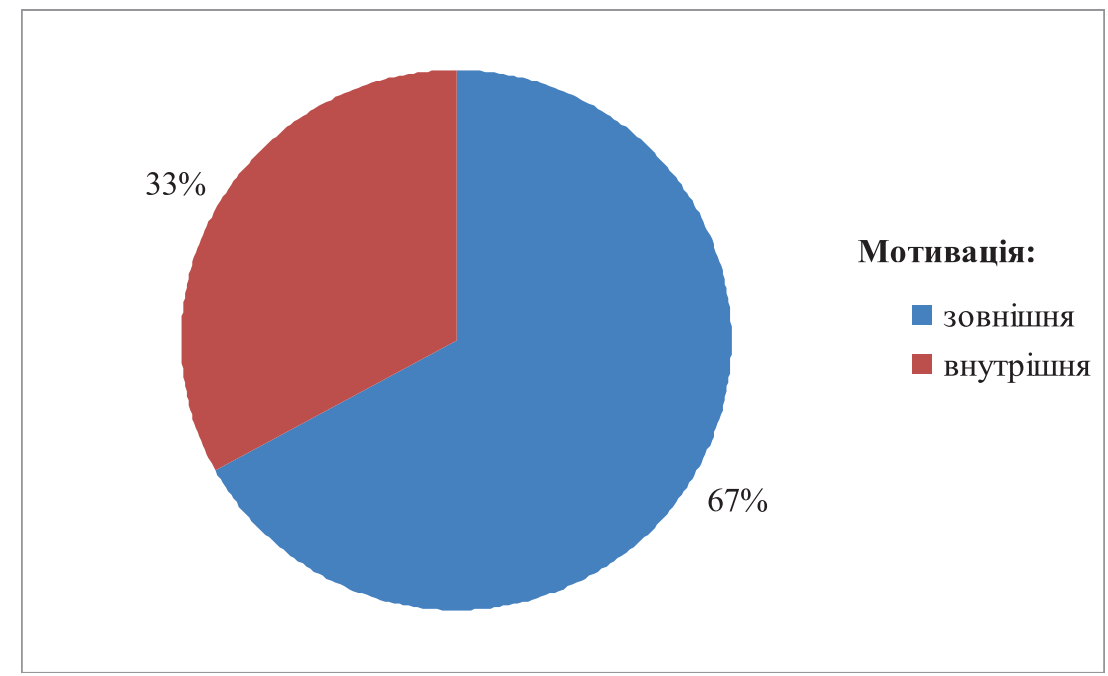

Рис. 2. Різновиди мотивації студентів до іншомовної підготовки

На запитання анкети «Які зовнішні чинники здатні підвищити внутрішню мотивацію студентів до іншомовної підготовки?» отримали наступні відповіді, варіанти яких подаємо за ступенем першочерговості:

1) навчальна практика на закордонних енергетичних об'єктах;

2) вивчення вибіркових фахових дисциплін іноземною мовою;

3) актуальна технічна література іноземного видавництва;

4) використання інноваційних технологій, сучасних методик 
навчання на практичних заняттях 3 дисциплін «Іноземна мова за професійним спрямуванням», «Ділова іноземна мова»;

5) організація і здійснення позааудиторної роботи студентів 3 іноземної мови.

Вважаємо, що зазначені вище чинники можуть ефективно впливати на формування мотиваційної сфери майбутніх інженерівенергетиків за умови виникнення особистісного інтересу студентів до іншомовної підготовки та прагнення оволодіти метамовою спеціальності на високому рівні. Цілісне утворення iз навчальних, професійних, комунікативних, особистісних, соціокультурних мотивів формує комплекс стимулюючих засобів, які спрямовані на позитивну налаштованість здобувачів спеціальності 141 «Електроенергетика, електротехніка та електромеханіка» до вивчення іноземної мови, що здійснюється під впливом зовнішньої та внутрішньої мотивації.

\section{Висновки}

За результатами експериментальної роботи досліджено мотиваційну сферу майбутніх інженерів-енергетиків, визначено комплекс мотивів, які утворюють їі структуру та закладають основу для формування внутрішньої і зовнішньої мотивації, виокремлено чинники, які зумовлюють іï виникнення та безперервний розвиток. На основі даних анкетування, проведених бесід та дискусій, спостереження за роботою студентів на практичних заняттях, зокрема у процесі вирішення комунікативних ситуацій загальнопобутового, країнознавчого, професійно-спрямованого характеру, власного досвіду констатуємо про середній рівень сформованості мотиваційної сфери студентів-енергетиків до вивчення іноземної мови.

Перспективи подальших досліджень вбачаємо в науковому обгрунтуванні та методичній розробці освітньої технології, яка б сприяла формуванню особистісних мотивів та позитивної мотивації студентів до компетентного оволодіння метамовою спеціальності, а результат мотивованоїіншомовної підготовкизабезпечив професійну мобільність інженерів-енергетиків у майбутній діяльності за фахом. 


\section{Література}

1. Арістова Н.О. Формування мотивації вивчення іноземної мови у студентів вищих нелінгвістичних закладів : автореф. дис. ... канд. пед. наук: 13.00.04. Київ, 2008. 20 с.

2. Гончаренко С. Український педагогічний словник. Київ: «Либідь», 1997. 376 с.

3. Енциклопедія освіти. Київ: «Юрінком Інтер», 2008. 1040 с.

4. Клименко Н.О. Формування мотивів навчально-пізнавальної діяльності студентів вищих навчальних закладів гуманітарного профілю : автореф. дис. ... канд. пед. наук : 13.00.04. Луганськ, 2005. $22 \mathrm{c}$.

5. Клочко В.І.,Коломієць А.А.Формування мотиваціїнавчальнопізнавальної діяльності студентів технічних спеціальностей: монографія. Вінниця: ВНТУ, 2012. 188 с.

6. Коломієць А.А. Формування мотивації навчальнопізнавальної діяльності студентів технічних спеціальностей засобами історіографії : дис. канд. пед. наук: 13.00.04. Вінниця, 2011. 271 с

7. Подшивайлов Ф.М. Психологічні чинники розвитку мотиваційної сфери особистості майбутнього психолога : дис. канд. псих. наук: 19.00.07. Київ, 2015. 238 с.

\section{Білан Н.М.}

\section{Дослідження мотиваційної сфери майбутніх інженерів- енергетиків до вивчення іноземної мови}

\section{Анотація}

У статті висвітлюються питання дослідження структурних компонентів мотиваційної сфери студентів до вивчення іноземної мови професійного спрямування. Встановлено, що від сформованості мотивації залежить результат іншомовної підготовки майбутніх інженерів-енергетиків, рівень засвоєння метамови спеціальності. Виокремлено види мотивів, які спонука- 
ють студентів оволодіти іншомовною компетентністю. Розкрито сутність поняття «мотив майбутніх інженерів-енергетиків до вивчення іноземної мови». Сформовано рейтинг вивчення дисциплін циклу загальної підготовки студентами за особистісними мотивами. Визначено пріоритетність «Іноземної мови за професійним спрямуванням» серед гуманітарних предметів, вивчення яких передбачене освітньо-професійною програмою підготовки здобувачів спеціальності 141 «Електроенергетика, електротехніка та електромеханіка». Виділено зовнішні чинники, які підвищують внутрішню мотивацію студентів до іншомовної підготовки. За результатами емпіричного дослідження встановлено, що мотиваційна сфера майбутніх інженерів-енергетиків до вивчення іноземної мови професійного спрямування сформована на середньому рівні.

Ключові слова: мотиваційна сфера, мотив, мотивація, іноземна мова, майбутні інженери-енергетики, студент.

\section{Билан Н.Н.}

\section{Исследование мотивационной сферы будущих инженеров- энергетиков к изучению иностранного языка}

\section{Аннотация}

В статье освещаются вопросы исследования структурных компонентов мотивационной сферы студентов к изучению иностранного языка профессионального направления. Установлено, что от сформированности мотивации зависит результат иноязычной подготовке будущих инженеров-энергетиков, уровень усвоения метаязыка специальности. Определены виды мотивов, которые побуждают студентов овладеть иноязычной компетентностью. Раскрыта сущность понятия «мотив будущих инженеров-энергетиков к изучению иностранного языка». Сформирован рейтинг мотивированного изучения дисциплин цикла общей подготовки студентами по личностным мотивам. Опреде- 
лено приоритетность «Иностранного языка профессиональной направленности» среди гуманитарных предметов, изучение которых предусмотрено образовательно-профессиональной программой подготовки соискателей специальности 141 «Электроэнергетика, электротехника и электромеханика». Выделены внешние факторы, которые способны повысить внутреннюю мотивацию студентов к иноязычной подготовки. По результатам эмпирического исследования установлено, что мотивационная сфера будущих инженеров-энергетиков к изучению иностранного языка профессионального направления сформирована на среднем уровне.

Ключевые слова: мотивационная сфера, мотив, мотивация, иностранный язык, будущие инженеры-энергетики, студент. 